\title{
Arboviruses and Sexually Transmitted Infections in the Bioceanic Route: Health Indicators in a Municipality
}

\author{
Paloma Almeida Kowalski' ${ }^{1}$ João Pedro Arantes da Cunha1 ${ }^{1}$, Erika Kaneta Ferri ${ }^{1}$ (D), \\ Natália Scigliano', Rachel Carvalho Lemos', Emily Ruiz Cavalcante1, \\ Vitor Keisi Medeiros Kataoka1, Fabiana Moreira Coutinho', Elton Hiroyuki Ytamura Moriya², \\ Leonardo Marzola Hirataㄹ, Gabriela Félix Dias Lima1, Letícia Roque Ribeiro', \\ Lucas Matheus Pinto², Sávio Carvalho Cobianchi³ ${ }^{3}$ Paulo Otávio Souza Leonel ${ }^{3}$
}

\author{
${ }^{1}$ State University of Mato Grosso do Sul (UEMS-UniversidadeEstadual de Mato Grosso do Sul), Campo Grande, MS, Brazil \\ ${ }^{2}$ Federal University of Mato Grosso do Sul (UFMS-Universidade Federal de Mato Grosso do Sul), Campo Grande, MS, Brazil \\ ${ }^{3}$ University for the Development of the State and Region of the Pantanal (UNIDERP_Universidade para o Desenvolvimento do \\ Estado e da Região do Pantanal), Campo Grande, MS, Brazil \\ Email: palomaakowalski@gmail.com
}

How to cite this paper: Kowalski, P.A., da Cunha, J.P.A., Ferri, E.K., Scigliano, N., Lemos, R.C., Cavalcante, E.R., Kataoka, V.K.M., Coutinho, F.M., Moriya, E.H.Y., Hirata, L.M., Lima, G.F.D., Ribeiro, L.R., Pinto, L.M., Cobianchi, S.C. and Leonel, P.O.S. (2021) Arboviruses and Sexually Transmitted Infections in the Bioceanic Route: Health Indicators in a Municipality. Advances in Infectious Diseases, 11, 344-356. https://doi.org/10.4236/aid.2021.114031

Received: September 26, 2021

Accepted: October 29, 2021

Published: November 1, 2021

Copyright $\odot 2021$ by author(s) and Scientific Research Publishing Inc. This work is licensed under the Creative Commons Attribution International License (CC BY 4.0).

http://creativecommons.org/licenses/by/4.0/

\section{(c) (i) Open Access}

\begin{abstract}
Background: the physical integration of South America through a Bioceanic Corridor has been idealized for a long time by the countries that make up Mercosur. This integration will have impacts on the population residing in the cities where the route will be built. Among them, Porto Murtinho, southern Mato Grosso on the border with Paraguay, stands out, where a bridge will be built over the Paraguay River that will link these two countries. Methods: a retrospective, quantitative and cross-sectional study of a descriptive type of documentary approach that sought to analyze the prevalence of arboviruses, Sexually Transmitted Infections (STIs) and Diseases Related to Inadequate Environmental Sanitation (DRIES) notified and stored in the National System of Notifiable Diseases (SINAN). The sample consisted of new cases of these pathologies in the municipality of Porto Murtinho registered between January 2017 and December 2020. Results: there was an increase of 10\% in the total number of diseases within this period. The number of dengue cases increased 36 times; the incidence of Syphilis, HIV and HPV decreased; and, finally, maintenance of cases of Gonorrhea, Leptospirosis, Yellow Fever, Zika, Chikungunya, Hepatitis A and B. Conclusions: actions are needed to prevent the increase of these pathologies together with the construction of the Bioceanic Route, thus avoiding damage population health and increased consumption of government resources.
\end{abstract}




\section{Keywords}

Bioceanic Route, Epidemiology, Public Health, Sexually Transmitted

Diseases, Arboviruses

\section{Introduction}

The physical integration of South America is part of a project conceived for a long time by countries that make up Mercosur. The aspired integration will take place through a Bioceanic Corridor that will connect the Atlantic Ocean to the Pacific, crossing four countries: Brazil, Paraguay, Argentina and Chile [1].

The Bioceanic Corridor has been a topic of discussion in Brazil since mid-2006. However, it was only in 2017 that the subject was matured, focused on the potential for carrying out the project for the State of Mato Grosso do Sul. It will foster the State's economy both in terms of logistics companies and in terms of strengthening its tourist potential [2].

The route will link the Brazilian territory to the Chilean and Peruvian coasts, allowing access to the Pacific Ocean and not only to the Atlantic, as it is currently done [3]. However, such an undertaking could also cause a series of losses for the local population in general. Some of them in the social sphere, such as the distortion of the age pyramid, the occupational profile of the region, increase in violence and prostitution. Added to this is the fact that such works can cause environmental damage, mainly harming the local riverside population [4].

In addition, the intensification of interaction between the construction workers, many of them foreigners, with the Brazilian population and its territory may lead to an exacerbation of the transmission of pathologies such as arboviruses and Sexually Transmitted Infections [5].

The permanence of these workers in Brazilian territory will lead to a rapid increase in population in the border towns connected by the Bioceanic corridor. The occurrence of population increase, without prior planning or compatible structural adjustments, such as the expansion of basic sanitation, will lead to an increase in the incidence of "Diseases Related to Inadequate Environmental Sanitation (DRIESI)" [6].

Given the above, this research aims to identify and analyze the Health indicators of the Municipality of Porto Murtinho-MS. With this, it will be possible to better clarify the dynamics of environmental and epidemiological changes related to health resulting from the construction of the Bioceanic corridor. Therefore, the results obtained with this research may also serve as a basis for future studies that involve the construction of large works. Added to this, it may also provide subsidies for future interventions in the field of collective health.

In the state of Mato Grosso do Sul, the route will pass through the municipality of Porto Murtinho (MS), on the border with Paraguay, located in the south of the Pantanal, on the banks of the Paraguay River. The municipality has more 
than 15 thousand inhabitants, with $80 \%$ of the municipality's population living mainly from fishing tourism [7].

Regarding this expansion of the agricultural frontier, the rapid deforestation resulting from the construction of the Bioceanic route will cause, in addition to the contamination of the tributaries, the displacement of vectors or etiological agents of various diseases, thus affecting the populations directly involved with the enterprise and the communities located near the area. It also tends to affect, in a second moment, even entire populations [8].

It should also be noted that the isolation of more than 545 species of arboviruses has already been carried out, among which more than 150 are the cause of pathologies in human beings. Some epidemiologically most important examples for Brazil include dengue, Zika, Chikungunya and yellow fever [9].

Also, the large Investment Projects became the cause of territorial intervention. Despite variations in its effects, the distortion of the age pyramid, the disruption of family and neighborhood ties, increased violence, prostitution, trade and drug use, temporary change in the occupational profile without planning for recomposition or maintenance stand out, from previous economic activities or to create new activities after the works, remodeling the territory with the conversion of the area or city [4].

There is also a great possibility of social problems such as sexual exploitation, urban violence, basic sanitation and lack of access to goods and services. Thus, places impacted by major works, in general, show an accelerated increase in cases of sexual violence against children and adolescents, establishing a relationship inversely proportional to the State's capacity to meet and resolve this new demand [4].

On the other hand, prostitution and drug use mentioned above, such practices involve risk behaviors for contracting Sexually Transmitted Infections (STIs) such as Syphilis, Trichomoniasis, Hepatitis B, Gonorrhea, Human Papilloma Virus (HPV) and the Virus of Human Immunodeficiency (HIV) as the establishment of multiple sexual partners and the inconsistent use of condoms [5].

The lack of basic sanitation resulting from the large population increase without prior planning and adjustments may also affect the population of the cities involved, causing several negative impacts on the population's health. The so-called "diseases related to inadequate environmental sanitation (DRIESI)" are related to the lack or insufficiency of environmental sanitation and precarious housing conditions. DRIESI involves pathologies such as diarrhea, leptospirosis, Chagas disease, taeniasis and hepatitis A [6].

Another important impact will be in the area of health care, since with the arrival of tourists brought along the route and even foreign workers involved in its construction who eventually contract some pathology in Brazilian territory, such individuals can be assisted, in an emergency, by the Unified Health System (SUS) highlighting the fact that care can be precarious depending on the location and the care post, further overloading the Brazilian health system. 
Therefore, the construction of the Bioceanic Route involves the generation of a wide variety of possible impacts to be exerted mainly on the Health of the population of the cities most involved in this process, such as the population of Porto Murtinho. Thus, there is an evident need for studies carried out before, during and after the completion of this work, aiming to identify the existence of changes in Health indicators and thus better clarify the dynamics of environmental and population changes that involve the construction of large works, like this one, within the State of Mato Grosso do Sul and in Brazil as a whole.

This research aims to identify and analyze the Health indicators of the Municipality of Porto Murtinho-MS. With this, it will be possible to better clarify the dynamics of environmental and epidemiological changes related to health resulting from the construction of the Bioceanic corridor. Thus, the results obtained with this research may also serve as a basis for future studies that involve the construction of large works. Added to this, it may also provide subsidies for future interventions in the field of collective health.

\section{Methods}

The research was carried out through a retrospective, quantitative and crosssectional study, descriptive and documentary approach. This method is indicated in order to understand logical reasoning and all measurable information about human experiences, generating accurate results and ensuring greater security in relation to the inferences obtained [10] [11] [12].

The sample consisted of all new and old cases of arboviruses, STI's and DRIESI notified by the health services and stored through the Notifiable Diseases Information System (SINAN), in the municipality of Porto Murtinho, state of Mato Grosso do Sul, in the period from January 2017 to December 2020. The study inclusion criteria met were all diseases occurred and reported within the period from January 2017 to December 2020 in the Municipality of Porto Murtinho-MS. Diseases notified as suspected, but discarded later, were excluded. The arboviruses, Sexually Transmitted Infections (STIs) and Diseases Related to Inadequate Environmental Sanitation (DRIES) were defined accorndingly to the ones presente in the National Notification System in Brazil, which uses the International Classification of Diseases (ICD) as a standard for stratification and assignment of each disease.

Limitations of the study included: smal setting, the study was conducted in a sole capital of Brazil, in the State of Mato Grosso do Sul, incompleteness of some blank fields from the data in the archives stored nationally, which were not included in the study analysis, and burocracy to attend to the database.

This research complied with the ethical precepts of the Resolution of Research Involving Human Beings contained in Resolution National Health Council (CNS) n0 466 of December 12, 2012 and Resolution n0 510 of April 7, 2016. Exemption from the TCLE, Term of Consent granted by the State Health Department of Mato Grosso do Sul and Term of Consent for the Use of Database, 
ensuring the confidentiality of the research. The project was approved by the Ethics and Research Committee - CEP/CONEP system.

The data obtained were analyzed regarding the following variables: ICD-10 of the health problem, Type of notification, date of notification of the health problem, date of onset of the first symptoms, Race/Color of the patient, Education, Presence of Pregnancy, Gestational Age, Age and Gender. As this is a census, sampling techniques and sample size calculation were not necessary. The present work identified and analyzed the Health Indicators of the Porto Murtinho-MS Population. Data tabulation was performed using the Excel 2016 program and data analysis and crossing using the GraphPad Prism 7 software.

\section{Results}

From January 2017 to December 2020, the following cases of STIs were reported: 35 cases of Acquired Human Immunodeficiency Syndrome (AIDS/HIV); 148 cases of syphilis; 1233 cases of Condyloma Acuminata (HPV-Human Papilloma Virus) and no cases of Hepatitis B and Gonorrhea.

In the context of arboviruses, 489 cases of dengue, 8 of Chikungunya, 7 of $\mathrm{Zi}$ ka virus and 1 of yellow fever were reported in the same period. Furthermore, with regard to Diseases Related to Inadequate Environmental Sanitation (DRIESI), there were 3 cases of leptospirosis, 1 suspected of Chagas disease, which was later discarded, and none of hepatitis A. Such distributions, excluding the etiologies for which they were not Ssuspected or confirmed cases are reported on the next table (Table 1).

Table 1. Distribution of infectious diseases notified by year and percentage of each of them among the sum of total notifications for the period 2017 to 2020 .

\begin{tabular}{ccccccc}
\hline Diseases & 2017 & 2018 & 2019 & 2020 & N & $\%$ \\
\hline STI & & & & & & \\
\hline HPV & 294 & 402 & 321 & 216 & 1.233 & 64.21 \\
Syphilis & 53 & 62 & 24 & 16 & 155 & 8.07 \\
HIV & 11 & 12 & 5 & 7 & 35 & 1.8 \\
\hline Arboviruses & & & & & & \\
\hline Dengue & 13 & 32 & 160 & 272 & 477 & 24.84 \\
Chikungunya & 1 & 2 & 4 & 1 & 8 & 0.41 \\
Zika & 1 & 1 & 2 & 3 & 7 & 0.36 \\
Yellow fever & 1 & 0 & 0 & 0 & 1 & 0.05 \\
\hline DRIES & & & & & & \\
\hline Syphilis & 1 & 1 & 1 & 0 & 3 & 0.15 \\
Sore disease & 1 & 0 & 0 & 0 & 1 & 0.05 \\
Total & 376 & 512 & 517 & 515 & 1.920 & 100 \\
\hline
\end{tabular}

Source: data extracted from SINAN (2021). 
Regarding STIs, the etiology with the highest incidence was HPV, diagnosed in these cases through the manifestation of condyloma acuminatum. The highest incidence occurred in 2018: 402 (32.6\%) cases; followed by 321 (26.03\%) in 2019; $294(23.84 \%)$ cases in 2017 and $216(17.51 \%)$ in 2020. With this, in relation to HPV notifications, there is an increase in the number of cases in 2018 followed by a gradual decrease in incidence until reaching the lowest number of cases in 2020 , thus decreasing by $26.53 \%$ compared to the number of cases registered in 2017.

Regarding the profile of patients diagnosed with HPV, most were male (67.63\%) and mixed race $(33.33 \%)$ individuals. In addition, HPV was diagnosed in 53 pregnant women, of which the majority (58.49\%) was in the 3rd gestational trimester, with 31 cases. Most participants were from the adult age group (19 to 59 years), corresponding to 1152 (93.43\%) individuals. Regarding education, most patients had at least higher education, 634 (51.42\%) individuals (Table 2).

The second largest etiology of STI among those surveyed was Syphilis, in its various presentations. In the period from January 2017 to December 2020, a total of 84 cases of Acquired Syphilis were reported, corresponding to 54.19\% of the total cases reported in the period; 57 (36.77\%) of syphilis in pregnant women and 7 (4.51\%) of congenital syphilis (Table 3 ).

Regarding the temporal distribution of Syphilis cases, most of them occurred in the year 2018: 62 (40\%) cases; followed by 53 (34.19\%) in 2017; 24 in 2019 (15.48\%) and 16 in 2020 (10.32\%). Thus, it can be observed that there was a decrease in incidence of $231 \%$ in 2020 compared to the number reported in 2017.

Most occurred in females, with 99 cases (63.87\%). Among the subgroup of acquired syphilis (84 cases total - 100\%), the majority, with 56 cases (66.66\%), were male. The predominant race was again brown, with $36(42 \%)$ individuals, followed by $32(38.09 \%)$ white, $7(0.08 \%)$ black, $1(0.01 \%)$ indigenous and 9 $(0.1 \%)$ did not inform their race.

Most had attended elementary school 55 (35.48\%); followed by 48 (30.96\%) with high school. Among the individuals, most of them were also in the adult age group, with 98 (62.80\%) between 21 and 60 years, followed by 34 (21.93\%) individuals in the range between 11 and 20 years and $12(7.74 \%)$ were over 60 years old.

Regarding treatment, more than half of the individuals with acquired syphilis $(47 \%-55.95 \%)$ were treated with administration of Penicillin Benzatine at a dose of 4.8 million IU, corresponding to the treatment recommended by the Ministry of Health for secondary syphilis; $2(0.02 \%)$ were treated with the same drug at a dose of 2.4 million IU, treatment, recommended for primary syphilis; the remainder of the 35 (41.66\%) diagnosed had no mode of treatment informed in the notification form. Furthermore, regarding the evolution of these cases, 32 (38.09\%) progressed to cure and the rest were not informed.

Furthermore, with regard to the Syphilis in Pregnancy subgroup, most women: $25(43.85 \%)$ were in the 2 nd trimester of pregnancy at the time of diagnosis, followed by $20(37.03 \%)$ pregnant women in the 1st trimester, $11(19.29 \%)$ in the 
3rd trimester and $1(0.01 \%)$ was unable to inform the gestational age. Of this total, none evolved to death. Regarding the 7 cases of the subgroup of congenital syphilis notified, none died due to the pathology, with all 7 (100\%) cases treated progressing to cure.

Table 2. Distribution regarding the sociodemographic profile of patients infected with condyloma between 2017 and 2020 .

\begin{tabular}{|c|c|c|}
\hline Variable & $\mathrm{N}=1233$ & $\%$ \\
\hline \multicolumn{3}{|l|}{ Gender } \\
\hline Men & 833 & 67.56 \\
\hline Women & 400 & 32.44 \\
\hline \multicolumn{3}{|l|}{ Color/race } \\
\hline White & 365 & 29.60 \\
\hline Black & 28 & 2.27 \\
\hline Yellow & 48 & 3.90 \\
\hline Brown & 411 & 33.33 \\
\hline Indigenous & 9 & 0.73 \\
\hline Ignored & 372 & 30.17 \\
\hline \multicolumn{3}{|l|}{ Age } \\
\hline Child ( 0 - 11 years $)$ & 16 & 1.30 \\
\hline Teenager (12 - 18 years) & 20 & 1.62 \\
\hline Adults (19 - 59 years) & 1152 & 93.43 \\
\hline Above 60 years & 45 & 3.65 \\
\hline \multicolumn{3}{|l|}{ Scholars } \\
\hline Illiterates & 21 & 1.70 \\
\hline Elementary school & 371 & 30.10 \\
\hline High school & 157 & 12.73 \\
\hline University education or above & 634 & 51.42 \\
\hline Ignored & 50 & 4.05 \\
\hline \multicolumn{3}{|l|}{ Notification year } \\
\hline 2017 & 291 & 23.60 \\
\hline 2018 & 402 & 32.60 \\
\hline 2019 & 321 & 26.04 \\
\hline 2020 & 219 & 17.76 \\
\hline \multicolumn{3}{|l|}{ Pregnant } \\
\hline Yes & 53 & 4.30 \\
\hline No & 319 & 25.87 \\
\hline Not applicable & 861 & 69.83 \\
\hline \multicolumn{3}{|l|}{ Gestational age $(\mathrm{N}=53)$} \\
\hline $1^{\circ}$ Trimester & 9 & 16.98 \\
\hline $2^{\circ}$ Trimester & 9 & 16.98 \\
\hline $3^{\circ}$ Trimester & 31 & 58.49 \\
\hline Ignored & 4 & 7.55 \\
\hline
\end{tabular}

Source: data extracted from SINAN (2021). 
Table 3. Distribution of acquired, gestational and congenital syphilis cases registered from 2017 to 2020 .

\begin{tabular}{ccccccc}
\hline Syphilis & 2017 & 2018 & 2019 & 2020 & $\mathrm{~N}$ & $\%$ \\
\hline $\mathrm{N}^{\bullet}$ cases/year & & & & & & \\
\hline Acquired syphilis & 24 & 40 & 10 & 10 & 84 & 56.75 \\
Gestacional syphilis & 25 & 14 & 13 & 5 & 57 & 38.51 \\
Congenital syphilis & 4 & 1 & 1 & 1 & 7 & 4.7 \\
\hline Gender & 15 & 30 & 4 & 7 & 56 & 36.12 \\
\hline Men & 38 & 32 & 20 & 9 & 99 & 63.87 \\
\hline Women & 376 & 512 & 517 & 515 & 1.920 & 100 \\
\hline Total & & & & & & \\
\hline
\end{tabular}

Source: data extracted from SINAN (2021).

Regarding HIV, it ranked 3rd in incidence among the STIs analyzed. The year with the highest incidence was 2018, in which 12 (34.28\%) cases of the disease were reported, followed by $11(31.42 \%)$ cases in 2017, 7 (20\%) in 2020 and 5 (14.3\%) in 2019. Thus, at the end of 2020, there was a decrease in the number of cases compared to 2017 by $54.8 \%$.

The largest number of HIV cases occurred in the adult age group (19 to 59 years), corresponding to a total of 32 cases (91.43\%), followed by children between 0 and 11 years old with 2 cases (5.72\%) and elderly over 60 years old with 1 case $(2.85 \%)$. Just over half of the cases, $19(54.28 \%)$ were male and 16 (45.71\%) were female. Most, 21 (59.99\%) of the individuals had attended Elementary School. Only one was pregnant $(2.85 \%)$ upon receiving the HIV diagnosis. In the evolution of the cases, 2 (5.71\%) individuals died from the disease.

In the context of arboviruses, the etiology with the highest number of reported cases in the period from January 2017 to December 2020 was dengue, with 489 (100\%) cases. The second-largest etiology was Chikungunya, with 8 cases, 1 (12.5\%) in 2017, 2 (25\%) in 2018, 4 (50\%) in 2019 and $1(12.5 \%)$ in 2020.

\section{Discussion}

Over the analyzed periods, there were 1,920 notifications of infectious diseases. Of this total, 376 notifications were made in 2017, corresponding to a total of $19.58 \%$ of the grievances in the analyzed period. In 2018, in turn, 512 injuries were registered (26.66\% of injuries); in 2019 there were 517 (26.92\%) and in 2020 there were $515(26.82 \%)$. With this, there is a significant increase in the total number of injuries over the period, reaching a peak in 2019 and practically maintaining itself in 2020. Therefore, there was an increase in the incidence of injuries of 7.54\% compared to the year of the beginning of the analysis in 2017, the year it ends in 2020 .

Regarding STIs, primarily HIV, there is an increase in the number of cases in 
2018 (12 cases), increasing by $8.33 \%$ compared to the number of cases in the previous year (11 cases) and reaching peak incidence. In 2019, the incidence of the pathology reduced again, reaching a value lower than the initial (5 cases), reducing by more than $50 \%$ compared to the previous year. Finally, in 2020 the number of registered cases was again 12, an incidence equal to the initial one in 2017. Therefore, with regard to HIV, the most significant increase occurred in 2018 and there was the maintenance of the incidence when comparing the beginning year from analysis to the year of completion.

As for HIV, public policies to combat HIV/Aids were implemented in the 1990s, based on the universal and free offer of antiretroviral therapy (ART) through the public health system, recognized worldwide for the significant reduction in morbidity and mortality, but which presents difficulties in maintain the sustainability of the actions in the long term [13]. In this sense, social inequalities in Brazilian regions contribute to the maintenance of the high incidence of HIV, given that this pathology has undergone profound epidemiological changes, which is no longer restricted to urban centers and today is in a process of interiorization, pauperization, heterosexualization and feminization [14]. Thus, the epidemiological transitions pointed out to corroborate the data found in this study on HIV.

Already related to HPV, this is the most transmissible STI, surpassing HIV and genital herpes infections since with each new sexual partner the risk of infection for this pathology is $15 \%$ to $25 \%$ [15]. Therefore, the importance of analyzing the incidence of HPV is highlighted, to which it is also added that this disease in $99 \%$ of cases is associated with the severity of cervical cancer [16]. Thus, in the municipality of Porto Murtinho-MS, it was ibserved an increase of its incidence in the year 2018 (402 cases), resulting in an increase in the number of cases of approximately 25\% when compared to the previous year, when 294 cases of the pathology were registered. In 2019, in turn, there was a decrease in the incidence, with a record of 321 cases, a number close to the value of the previous year. In 2020, the number of cases reached even lower values: 216 , a reduction of $45.77 \%$ compared to the year when the analysis began, in 2017 . In some excerpts of the work, condyloma acuminatum is read, which is the first manifestation of HPV in most people and is also known as genital wart.

The use of condoms and vaccination are the known ways to prevent HPV, and the latter form stands out for its greater effectiveness demonstrated by clinical studies for both the quadrivalent vaccine (HPV4) and the vaccine against oncogenic HPV (HPV2) [17]. It can be seen, therefore, that the vaccination against HPV instituted in Brazil coincides with the decline in the incidence rates presented in the studied municipality, thus, long-term research is needed to consolidate this data.

In turn, with regard to the incidence of syphilis, a decrease in the number of cases was observed over the years. The year with the highest number of cases was 2018, which registered 62 (40\%) cases; followed by 53 in 2017 (34.19\%). There 
was a significant drop in the number of cases in 2019, when 24 cases were registered, reducing the incidence by approximately $50 \%$ compared to the previous year. In 2020, in turn, there was a decrease in the number of cases by approximately $30 \%$ compared to 2019 and by approximately 4 times compared to the value registered in 2017. It is important to remember that large cases of Syphilis are treated with penicillin $\mathrm{G}$ benzathine, available in most health centers, being an easy and fast treatment and being of fundamental importance for the reduction of syphilis cases. It is also added that control measures aimed at the patient and partner, new laboratory tests, use of condoms and health education aimed at the population are part of the programs adopted in Brazil aimed at reducing and combating syphilis [18]. During all these years there were no reported cases of Hepatitis B and Gonorrhea, the incidence being maintained.

Therefore, in relation to STIs, there was a significant increase in their incidence, mainly in 2018, decreasing later. This may be a reflection of both the increased diagnosis and the changes imposed by the Bioceanic Route in the social sphere, increasing marginalization, sexual violence and risk behaviors and consequently leading to an increase in the incidence of STIs in the construction of large works in the Amazon [4].

In the context of DRIESI, the highest incidence was of leptospirosis, with 3 cases registered, 1 in each year from 2017 to 2019 and none in 2020 (100\% decrease in incidence). With this, in relation to this group of diseases, it is considered that there was a reduction in 2020 when compared to the initial year. This fact can be caused by the non-transmission of such diseases or by the non-detection of them when they occur, noting that some of them, such as hepatitis A and B generally have, in most cases, a benign course, being asymptomatic or oligosymptomatic [19].

Regarding hepatitis A, it is symptomatic in up to $70 \%$ of adults. Symptoms may include nausea, vomiting, anorexia, fever, malaise and abdominal pain, followed by jaundice, choluria, acholia and itching, however, these symptoms of the acute phase of the disease usually present for days or weeks. After this period, jaundice may appear lasting the same period and then there is complete disappearance of these [20].

In hepatitis B $70 \%$ of adults do not have symptoms; the symptomatic $30 \%$ may have the same symptoms mentioned above for Hepatitis A. The risk of chronification for hepatitis B exists, but in adults it varies from $0 \%$ to $10 \%$ of cases. However, it is important to emphasize that this infection, when it occurs through vertical transmission, becomes chronic in $90 \%$ of cases, highlighting the importance of its diagnosis during pregnancy for the proper treatment of pregnant women and newborns [20].

On the other hand, in relation to arboviruses, primarily Dengue, there was a significant increase in incidence over the years analyzed, as well as there was a significant increase in the incidence of arboviruses during the analyzed period, mainly due to the increase in the number of dengue cases, a disease that reached a total increase of approximately 20 times compared to the initial value in 2017 . 
It is known that environmental changes generally affect the distribution of pathologies of infectious origin. There is a close connection between economic development, environmental conditions and health, given the fact that human interventions in the vectors' natural environment create conditions for their transmission [21].

With such interventions, rapid deforestation, displacement of vectors or etiological agents involved in the transmission of diseases to the human race can occur. The transmission will take place, at first, in populations directly involved with the project and in communities located close to the area. In a second moment, such diseases can be perpetuated to the outskirts of large cities and even entire populations [21].

On the other hand, the number of Chikungunya cases remained the same in 2017 and 2018, increasing by 4 times in 2019 and returning to the initial value in 2020. Finally, the incidence of Zika virus infection was maintained in 2017 and 2018: 1 case, doubling its incidence to 2 cases in 2019 and increasing by $50 \%$ in 2020 (3 cases). The number of yellow fever cases was 1 case in 2017, reducing its incidence to no cases in the following years.

\section{Conclusions}

The construction of the bioceanic corridor can influence municipalities' citizens directly involved in its construction, which may result in an increase in the incidence of multiple diseases. According to this study, over the years studied in the city of Porto Murtinho, there was an increase in the total number of pathologies by approximately $10 \%$ compared to the beginning period, from the initial year of 2017 to the final year of 2020 . However, there was also a decrease in several specific infectious diseases, such as syphilis and HPV, which may be a result of the success of preventive actions or a decrease in the effectiveness of actions aimed at its diagnosis, which can also be influenced by the occurrence of the pandemic in 2019, leading many to not seek medical care for fear of leaving their homes.

The incidence of Gonorrhea, Leptospirosis, Hepatitis B, Hepatitis A, Yellow Fever, Zika and Chikungunya cases was maintained. An increase in the number of dengue cases was evidenced, being the most expressive increase in this research. In addition, there has been an increase in HIV cases over the years, returning to the initial incidence of cases in 2020. Therefore, there is an evident need for actions aimed at preventing the increase of STIs, Arboviruses and DRIESI before, during and after the construction of the Bioceanic Route in view of the changes that will be imposed by it. Faced with the increase in the flow of people that is inevitable with the construction of this project, several outcomes are expected based on previous experiences already mentioned in this work, and it is up to the government and the population to work together so that the construction takes place in the best possible way. Therefore, the results obtained may also serve as a basis for future studies of methodology and also for future interventions in the field of public health. 


\section{Declarations}

\section{Ethics Approval and Consente to Participate}

The Project was approved by the National Research Ethics Committee, number 4.820 .530

\section{Availability of Data and Materials}

The data that support the findings of this study are available from the Ministry of Health, but restrictions apply to the availability of these data, which were used under license for the current study, and so are not publicly available. Data are however available from the authors upon reasonable request and with permission of the Ministry of Health.

\section{Authors' Contributions}

All authors contributed in the writing and work of this research, from data collection and analysis to further literature writting and approval.

\section{Conflicts of Interest}

The authors declare no conflicts of interest regarding the publication of this paper.

\section{References}

[1] Ferreira, M.L., Castilho, M.A. and Oliveira, E.M. (2019) Brasil, Paraguai, Argentina e Chile/Rota Bioceânica: Relações culturais no território vivido. Interações (Campo Grande), 20, 69-89.

[2] Asato, T.A., Constantino, M., Dorsa, A.C. and Mariani, M.A.P. (2019) Rota de Integração Latino-Americana (RILA) para o desenvolvimento turístico. Interações (Campo Grande), 20, 45-56.

http://www.scielo.br/scielo.php?script=sci_arttext\&pid=S1518-70122019000500045

[3] Oliveira, V.A. (2010) A infraestrutura de transportes como política governamental para o desenvolvimento regional e a integração sul-americana: Uma análisesobre as Rotas Bioceânicas em Mato Grosso do Sul. UFGD, Dourados.

https://repositorio.ufgd.edu.br/jspui/bitstream/prefix/1707/1/ValquiriadeAraujoOli veira.pdf

[4] Pinho, V.A. and Oliveira, A.C. (2014) Direitos Infanto-juvenis e Violência Sexual em Contexto de Grandes Obras: Reflexões e perspectivas. GTR, Belém, 186 p. https://www.researchgate.net/publication/303873055_Direitos_Infanto-Juvenis_e_ Violencia_Sexual_no_Contexto_de_Grandes_Obras

[5] Guimarães, R.A., Silva, L.N., França, D.D.S., Del-Rios, N.H.A., Carneiro, M.A.S. and Teles, S.A. (2015) Comportamentos de risco para doenças sexualmente transmissíveis em usuários de crack. Revista Latino-Americana de Enfermagem, 23, 628-634. http://www.scielo.br/pdf/rlae/v23n4/pt_0104-1169-rlae-23-04-00628.pdf https://doi.org/10.1590/0104-1169.0077.2597

[6] Siqueira M.S., Rosa R.S., Bordin, R. and Nugem, R.C. (2017) Internações por doenças relacionadas ao saneamento ambiental inadequado na rede pública de saúde da região metropolitana de Porto Alegre, Rio Grande do Sul, 2010-2014. Epidemiologia e Serviços de Saúde, 26, 795-806. 
http://www.scielo.br/scielo.php?pid=S2237-96222017000400795\&script=sci_abstrac t\&tlng=pt https://doi.org/10.5123/S1679-49742017000400011

[7] Campos, L. and Faria, A. (2020) Rota Bioceânica: O que é e seus impactos diretos e indiretos. ECOA, Campo Grande.

https://ecoa.org.br/rota-bioceanica-o-que-e-e-seus-impactos-diretos-e-indiretos/

[8] Faria, A. (2014) Hidrovia Paraná Paraguai: O Megaprojeto Rearticulado. Campo Grande (MS): ECOA, Campo Grande, 19 p.

https://ecoa.org.br/wp-content/uploads/2019/05/hidroviaparanaparaguai-megaproj etorearticulado-poralcidesfaria.pdf

[9] Lopes, N., Nozawa, C. and Linhares, R.E.C. (2014) Características gerais e epidemiologia dos arbovírus emergentes no Brasil. Revista Pan-Amazônica de Saúde, 5, 55-64. http://scielo.iec.gov.br/scielo.php?script=sci_arttext\&pid=S2176-6223201400030000 $7 \& \operatorname{lng}=\mathrm{pt} \& \mathrm{nrm}=\mathrm{iso}$ https://doi.org/10.5123/S2176-62232014000300007

[10] Aliaga, M. and Gunderson, B. (2002) Interactive Statistics. Prentice Hall, Hoboken.

[11] Richardson, R.J. (2008) Pesquisa Social: Métodos e Técnicas. 3a edição, Atlas, São Paulo, 334 p.

[12] Paschoarelli, L.C., Medola, F.O. and Bonfim, G.H.C. (2015) Características Qualitativas, Quantitativas e Quali-quantitativas de Abordagens Científicas: Estudos de caso na subárea do Design Ergonômico. Revista de Design, Tecnologia e Sociedade, 2 , 65-78.

[13] Szwarcwald, C.L. and Castilho, E.A. (2011) A epidemia de HIV/AIDS no Brasil: Três décadas. Cadernos de Saúde Pública, 27, S4-S5. https://doi.org/10.1590/S0102-311X2011001300001

[14] Brito, A.B., Castilho, E.A. and Szwarcwald, C.L. (2000) AIDS e infecção pelo HIV no Brasil: Uma epidemia multifacetada. Revista da Sociedade Brasileira de Medicina Tropical, 34, 207-217. https://doi.org/10.1590/S0037-86822001000200010

[15] Carvalho, N.S., et al. (2021) Protocolo Brasileiro para Infecções Sexualmente Transmissíveis 2020: Infecção pelo papilomavírus humano (HPV). Epidemiologia e Serviços de Saúde, 30, e2020790. https://doi.org/10.1590/s1679-4974202100014.esp1

[16] Carvalho, M.C.M.P. and Queiroz A.B.A. (2011) Mulheres Portadoras de Lesões Precursoras do Câncer do Colo do Útero e HPV: Descrição do Perfil Socioeconômico e Demográfico. DST-Jornal Brasileiro de Doenças Sexualmente Transmissiveis, 23, 28-33. https://doi.org/10.5533/2177-8264-201123107

[17] Mello, C.F. (2013) Vacinação contra papilomavírus humano. Einstein, 11, 547-549. https://doi.org/10.1590/S1679-45082013000400027

[18] Avelleira, J.C.R. and Bottino, G. (2006) Sífilis: Diagnóstico, tratamento e controle. Educação Médica Continuada-EMC. Anais Brasileiros de Dermatologia, 81, 111-126. https://doi.org/10.1590/S0365-05962006000200002

[19] De Vigilância Em Saúde, S. and Hepatites Virais, M.S. (2021) Coordenação-Geral de Documentação e Informação/SAA/SE Ministério Da Saúde (impressão e expedição) SIA, trecho 4 , lotes $540 / 610$.

[20] Duarte, G., Pezzuto, P., Barros, T.D., Mosimann, G. and Martinez-Espinosa, F.E. (2021) Protocolo Brasileiro para Infecções SexualmenteTransmissíveis 2020: Hepatites virais. Epidemiologia e Serviços de Saúde, 30, e2020834. https://doi.org/10.1590/s1679-4974202100016.esp1

[21] Pignatti, M.G. (2003) Saúde e Ambiente: As Doenças Emergentes no Brasil. Ambiente \& Sociedade, 7, 133-148. http://www.scielo.br/pdf/asoc/v7n1/23540.pdf 